\title{
MONITORING LAND USE DYNAMICS OF PERI-URBAN AGRICULTUTRE IN CENTRAL KENYA WITH RAPIDEYE SATELLITE IMAGERY
}

\author{
M. Willkomm ${ }^{\text {a }}$, P. Dannenberg ${ }^{\text {a }}$ \\ ${ }^{a}$ Institute of Geography, University of Cologne, Germany - (m.willkomm, p.dannenberg)@uni-koeln.de
}

Commission VIII, WG VIII/8

KEY WORDS: peri-urban Agriculture, Global South, sub-saharan Africa, urban land use dynamics, RapidEye

\begin{abstract}
:
The poster submitted to the ISPRS Congress 2016 in Prague illustrates the concept behind the research project in its initial stage. The project concerns recent dynamics of urban and peri-urban agriculture (PUA) in middle-size cities of central Kenya. On the date of submission, only general research ideas were presented due to the unavailability of remote sensing data at the early stage of the project.
\end{abstract}

\section{INTRODUCTION}

In the context of an increasing urbanisation in the Global South and especially in sub-Saharan Africa, urban and peri-urban agriculture (PUA) plays an important role for urban dwellers (Goddard, 2009; Moustier \& Danso, 2006). Recent studies show that the general growth of population has greater effects on smaller and middle-size cities than on bigger megacities (Cohen, 2006; Matuschke, 2009). Due to the increasing population pressure, Kenyan cities especially are affected by intense structural changes (Kiteme et al., 2008; Mubea \& Menz, 2012). These changes do not only include rapid land use dynamics, but also social-economic challenges (Lambin et al., 2001). In the context of growing city areas, new settlements arise in which PUA is implemented.

Due to a variety of economic, public and individual interests, recent structural changes involve conflicts and challenges for institutional urban planning (Asiama, 2006; Orsini et al., 2013), especially in the context of weak legal requirements. Assuming a market system whose price formation of plots is based on supply and demand, land use is determined by its value added (Forkuor \& Cofie, 2011). PUA is part of this system, even though it is not the main economic sector in cities. In opposition to traditional functions of PUA e.g. for food security, recent empirical studies have documented an increasing economic potential in sub-Saharan Africa (Cour, 2001; Dossa et al., 2011). Traditional production patterns are increasingly being replaced by marked orientated productions of cash crops. Thus, there is a rising number of urban stakeholders participating in PUA with professional cultivation systems on larger areas or in greenhouses. Reasons for this development are complex and connected to a growing economic potential of agriculture in general.

In the context of new area allocations, attention should be paid to PUA as well. Based on the literature (e.g. Orsini et al., 2013) and our own explorative local experiences, we note an increasing professionalisation and commercialisation of urban and peri-urban food production. These changes result in new urban structures with new economical dynamics, which have not yet been sufficiently researched. Even though PUA is considered as an important element of urban planning (Van Veenhuizen \& Danso, 2007), less is known about its spatial distribution and its influencing factors.

The poster submitted to the ISPRS Congress 2016 in Prague illustrates the concept behind the research project in its initial stage. General research ideas are presented due to the early stage of the project and unavailability of remote sensing data on the paper submission date.

The planned investigation tries to contribute to the research gap mentioned above by analysing (1) in how far PUA is effectively persistence or rather increasing in cities, (2) its spatial and socio-economic characteristics (e.g. location, products, market access, degree of commercialisation, etc.) and (3) the frame conditions and drivers (e.g. population pressure, supermarketisation, export markets, etc.) which helps to explain the observed structures. The targeted research goals are partially analysed in the literature, however, an overall synthesis of these findings is widely missing. Using a mix of remote sensing and socio-scientific methods, an interlinked approach is to be conducted to (1) contribute interdisciplinary scientific knowledge. Based on this findings, social problem areas can be detected to (2) derive solution approaches and policy options for local planning agencies. The empirical basis for the study is to be created by a regional focus on the two medium-size cities Nakuru and Nyeri in central Kenya.

\section{PLANNED METHODOLOGY}

The projected results of this study will contribute to a general understanding of urban land use dynamics and the significance of PUA. To reach the research goals a mixed-method approach is to be conducted that include land use classifications and qualitative field surveys of the peri-urban regions of Nakuru and Nyeri in central Kenya. The aim is to develop a spatially related typology of different forms of PUA based on both data sets. 
Thus, spatial patterns of the distribution of PUA in the context of an increasing urbanisation are to be investigated. We will particularly consider the arrangements of different types of PUA as a function of external geographic and economic parameters. These include, e.g. the distance to infrastructure facilities like transportation routes or the availability for water withdrawal. Other factors can be parameters that make higher-value ventures economically viable or even impossible (e.g. the proximity to military areas or flooding zones).

The selection of the two cities under investigation in central Kenya is made due to the local expertise of the authors and existing socio-economic structures in urban areas. In general, the primary sector is of great economic importance both in rural and urban areas in Kenya. Forkuor \& Cofie (2011) reported that two in three Kenyan families living in urban and peri-urban areas are participating in PUA and earn all or at least a part of their living with it. The socio-economic relevance for the planned research project is shown by the population structure of Nakuru and Nyeri. The middle-size cities are affected by an intense increase in population (Wiesmann et al., 2014). Nakuru is stated to have been the fastest growing city in Africa between 1990 and 2006 (annually about $13 \%$; UN-HABITAT, 2008).

The general concept of the methodical approach is depicted in figure 1. Data acquisition is operationalized by a combination of remote sensing and social-scientific methods. Whereas remote sensing data acquisition and mapping especially contribute to findings of spatial structures, qualitative field interviews are to explain more socio-economic related issues.

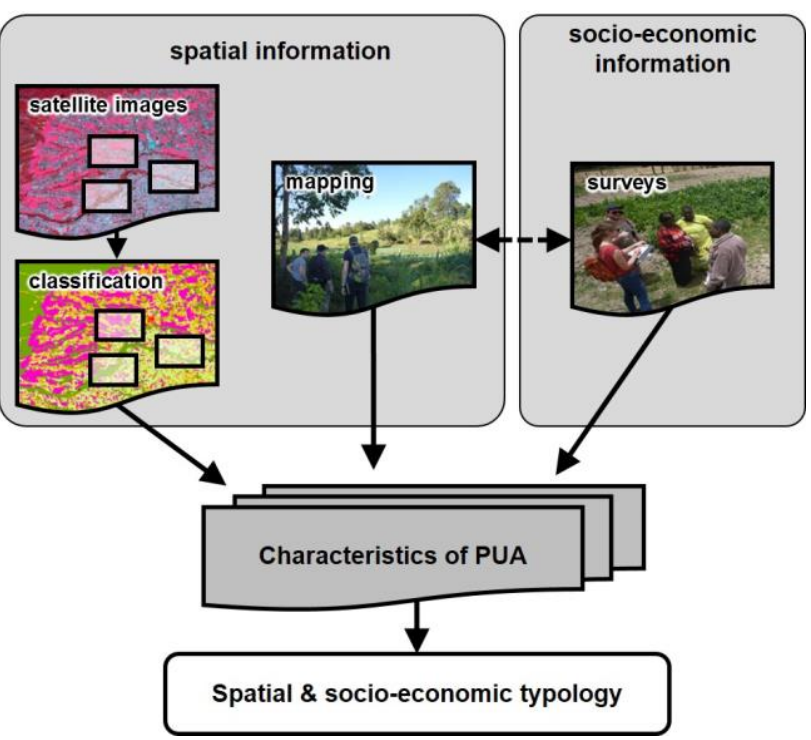

Figure 1: Methodical concept of the research project

In the literature a lack of quantitative spatial data in PUA research is emphasized (Dossa et al., 2011; Webb, 2011; Zezza \& Tasciotti, 2010). In this context, Pribadi \& Pauleit (2015) discuss that many studies about the role of PUA are often driven by advocacy investigations. By means of remote sensing analysis, we try to bridge this research gap. The application of established land cover classification tools is supposed to deliver comprehensive quantitative datasets. These approaches help to quantify PUA and to describe its characteristics. An integrated classification of PUA types is completed by mapping socioeconomic data. Comparable analyses often use satellite images with low spatial resolution (Forkuor \& Cofie, 2011; Mundia \&
Aniya, 2006; Pribadi \& Pauleit, 2015). Due to the small extent of many PUA types, high resolution data is required.

\section{REFERENCES}

Asiama, S., 2006. Land accessibility and urban agriculture in Freetown, Sierra Leone. Journal of Science and Technology, 25(2), pp. 103-109.

Cohen, B., 2006. Urbanization in developing countries: Current trends, future projections, and key challenges for sustainability. Technology in Society, 28(1-2), pp. 63-80.

Cour, J.M., 2001. The Sahel in West Africa: countries in transition to a full market economy. Global Environmental Change, 11(1), pp. 31-47.

Dossa, L.H., Abdulkadir, A., Amadou, H., Sangare, S. \& Schlecht, E., 2011. Exploring the diversity of urban and periurban agricultural systems in Sudano-Sahelian West Africa: An attempt towards a regional typology. Landscape and Urban Planning, 102(3), pp. 197-206.

Forkuor, G. \& Cofie, O., 2011. Dynamics of land-use and landcover change in Freetown, Sierra Leone and its effects on urban and peri-urban agriculture - a remote sensing approach. International Journal of Remote Sensing, 32(4), pp. 1017-1037.

Goddard, M.A., Dougill, A.J. \& Benton, T.G., 2009. Scaling up from gardens: biodiversity conservation in urban environments. Trends in Ecology \& Evolution, 25(2), pp. 90-98.

Kiteme, B.P., Liniger, H., Notter, B., Wiesmann, U. \& Kohler, T., 2008. Dimensions of Global Change in African Mountains: The Example of Mount Kenya. Regions: Laboratories for Adaptation, 2008(1), pp.18-22.

Lambin, E.F., Turner, B.L., Geist, H.J., Agbola, S.B., Angelsen, A., Bruce, J. W., Coomes, O. T., Dirzo, R., Fischer, G., Folke, C., George, P.S., Homewood, K., Imbernon, J., Leemans, R., Li, X., Moran, E.F., Mortimore, M., Ramakrishnan, P.S., Richards, J.F., Skanes, H., Steffen, W., Stone, G.D., Svedin, U., Veldkamp, T.A., Vogel, C. \& Xu, J., 2001. The causes of landuse and land-cover change: moving beyond the myths. Global Environmental Change, 11(4), pp. 261-269.

Matuschke, I., 2009. Rapid urbanization and food security: Using food density maps to identify future food security hotspots. In: International Associaton of Agricultural Economist Conference. Beijing, China, pp. 16-22.

Moustier, P. \& Danso, G., 2006. Local economic development and marketing of urban produced food. In: van Veenhuizen, R. (Eds.), Cities farming for the future. IDRC and IIRR Publishing, Leusden, pp. 171-206.

Mubea, K. \& Menz, G., 2012. Monitoring land-use change in Nakuru (Kenya) using multi-sensor satellite data. Advances in Remote Sensing, 2012(1), pp. 74-84.

Mundia, C.N. \& Aniya, M., 2006. Dynamics of landuse/cover changes and degradation of Nairobi City, Kenya. Land Degradation \& Development, 17(1), pp. 97-108. 
Orsini, F., Kahane, R., Nono-Womdim, R. \& Gianquinto, G., 2013. Urban agriculture in the developing world: a review. Agronomy for Sustainable Development, 33(4), pp. 695-720.

Pribadi, D.O. \& Pauleit, S., 2015. The dynamics of peri-urban agriculture during rapid urbanization of Jabodetabek Metropolitan Area. Land Use Policy, 48(0), pp. 13-24.

UN-HABITAT, 2008. State of African Cities 2008. A framework for addressing urban challenges in Africa. UNHABITAT, Nairobi.

Van Veenhuizen, R. \& Danso, G., 2007. Profitability and sustainability of urban and periurban agriculture. Food \& Agriculture Org, Rome.

Webb, N.L., 2011. When is enough, enough? Advocacy, evidence and critism in the field of urban agriculture. Development Southern Africa, 28(2), pp. 195-208.

Wiesmann, U., Kiteme, B. \& Mwangi, Z., 2014. SocioEconomic Atlas of Kenya: Depicting the National Population Census by County and Sub-Location. KNBS, Nairobi.

Zezza, A. \& Tasciotti, L., 2010. Urban agriculture, poverty, and food security: Empirical evidence from a sample of developing countries. Food Policy, 35(4), pp. 265-273. 